between 0 and 1 is by $[B]$ either $X$ or $X+1$, the even or odd value of $N$ being chosen according as $F(\alpha, \beta, \gamma, 1-0)$ is greater or less than 0 , viz., $1^{\circ}$ If $\nu>0$, according as $E(-\alpha)+E(-\beta)+E(-\gamma)$ is odd or even ; $2^{\circ}$ if $\nu<0$, according as $E(\alpha-\gamma)+E(\beta-\gamma)+E(-\gamma)$ is odd or even. If, however, in $1^{\circ}$ either $-\alpha$ or $-\beta$ is integral and positive $F(\alpha, \beta, \gamma, x)$ ceases to be linearly independent of the solution corresponding to the larger exponent of $x=1$, so that, by $[B], N=X$. Similarly in $2^{\circ}$, if $\alpha-\gamma$ or $\beta-\gamma$ is a positive integer, $N=X$ for the same reason.

YALE UNIVERSITY, February 12, 1900 .

\title{
THE SUMMER MEETING OF THE DEUTSCHE MATHEMATIKER-VEREINIGUNG AT MUNICH, SEPTEMBER, 1899.
}

Probably no mathematical society in the world brings together at its annual meetings so many illustrious mathematicians and exhibits an activity of such multifarious nature and far-reaching importance as the Deutsche Mathematiker-Vereinigung. Founded about a decade ago through the efforts of G. Cantor, W. Dyck and others, it has enjoyed the utmost prosperity. It is indeed to be regretted that its meetings are held so late in the summer that it is impossible, save in exceptional circumstances, for our own members to be present. Such a piece of good fortune befell me last year, and I hope the following personal reminiscences may prove interesting enough to justify their publication. For more details of scientific character I refer to the Chronik of the Vereinigung, the article by E. Lampe in the Naturwissenschaftliche Rundschau, (1899), p. 537, and the official Verhandlungen der Gesellschaft Deutscher Naturforscher und Aertze, Vogel, Leipzig, 1900.

The summer meetings of the Vereinigung are always held in connection with those of the Gesellschaft Deutscher Naturforscher und Aertze, which corresponds in Germany to our American Association for the Advancement of Science. This year the meeting was held September 17th to $23 \mathrm{~d}$ at Munich, a city justly celebrated for its scientific institutions and collections of art, for its beautiful surroundings, and for the good nature and kindly spirit of its population. 
Our first meeting was a general reception, of a purely social nature, held in the large Kaimsäle, Sunday evening. But large as these rooms were, the immense throng which had gathered in thousands from all parts of the world, but particularly from Germany, Austria and Switzerland, so filled them that it was all but impossible to move about. 'To find one's friends in such a crush was almost impossible, and I had almost given up the hope when I spied Wirtinger absorbed in an exchange of views on algebraic functions with Hensel. Near them were Gutzmer, Gordan, Czuber, Lampe, Pringsheim, Noether, and others. Some, like myself, were accompanied by their wives. Of course this first greeting after a long absence was animated and pleasant.

The business of the week began Monday morning and lasted till Friday afternoon. The Vereinigung held some of its meetings apart, and some in joint session with sections of the Gesellschaft. There were also general sessions in which everybody joined. The opening session of the Gesellschaft was of this last kind. This was held in the royal theater, which was literally crowded. Speeches of welcome were held by the first Geschäftsführer v. Winckel, by the honorary president, H. R. H. Prince Dr. Ludwig Ferdinand of Bavaria; by the Cultusminister v. Landmann; the Mayor, v. Borscht; the president of the Academy of Sciences, v. Zittel ; the prorector of the University, v. Heigel ; the director of the Polytechnicum, v. Hoyer ; and finally by the president of the Gesellschaft, Wirkl., Geh. Admiralitätsrat, Dr. Neumayer of Hamburg. Then after the customary telegrams of courtesy had been read before being sent off to the Emperor of Germany, the Prinzregent Luitpold of Bavaria, and H. R. H. Duke Dr. Karl Theodor of Bavaria, the addresses of the day were in order. The lion of the occasion was Nansen who was greeted with prolonged and hearty applause. His theme was: "Meine Forschungsreise nach der Nordpolregion und deren Ergebnisse."

The first session of the Vereinigung took place the same afternoon in the Polytechnicum. Addresses of welcome were made by Bauer on the part of his colleagues in Munich and by Noether as president of the Vereinigung. These were followed by the only address of the day, an appreciative sketch by Engel of the life and labors of Sophus Lie.

All day Tuesday was devoted by the Vereinigung in separate session to the reading of papers. The first address was by Klein who made some extremely interesting and valuable remarks in addition to Engel's paper of the day 
before. Lie and Klein were fellow-students at Paris. At the outbreak of the Franco-Prussian war Klein returned to Germany but remained in correspondence with $\mathrm{Lie}$, who at that time was deeply absorbed in his new Kugelgeometrie. As the Germans began to close in on Paris, Lie who was celebrated even in Norway, the home of such men as Nansen, for his powers as a pedestrian, proposed to make his way into Italy on foot. He got as far as Fontainebleau when he was arrested as a suspicious character. Suspicion was only heightened when his very unplausible intentions were learned. The examination of his scanty baggage confirmed the impression. His mathematical papers were supposed to be notes written in cypher on the military condition of the country he was traversing. Various mathematical terms were given a military meaning. The word Kugel was constantly occurring; these passages were thought to refer to the artillery. The word Complex was also frequently repeated. Through imperfect knowledge of German script this was read Lomley and was thought to refer to a certain Monsieur Lomley, perhaps another spy, at least to some officer or military agent. Lie protested his innocence, maintaining that his papers were not written in cypher, that they had nothing to do with military affairs, and in short that they were mathematics pure and simple. If this were indeed so, Lie's statements could be easily tested. As every one knows, the mathematics taught at the great military schools of France is of a very elevated nature. So an officer was summoned, doubtless one who was reputed to be expert in his mathematics and Lie was given a chance to prove his assertions. But, alas! Lie's Kugelgeometrie had never been taught at the École Polytechnique nor at St. Cyr, and so was utterly incomprehensible to his examinator, who became convinced that he had before him not only a spy, but a crazy one at that. So Lie was cast into prison until some weeks later, when at the instance of Darboux and other friends in Paris, he was released.

The two lprincipal papers of the day were by Hensel, "Ueber die analytisch-arithmetische Theorie der algebraischen Functionen von zwei Variablen"; and by Hilbert, "Ueber das Dirichlet'sche Princip." 'The latter, treating an old and celebrated problem with striking originality, excited universal surprise and admiration. As everyone knows, Riemann's epoch making researches in abelian functions rest on a half-mathematical, half-physical principle which Riemann called Dirichlet's Principle and which relates to the minimum of a certain integral. 
After Weierstrass's criticism it became necessary to give Riemann's theory a new foundation, which marred its original beauty and simplicity. Hilbert showed how the theory of ensembles, of partial differential equations, and the calculus of variations enable us to remove Weierstrass's objection and so return to Riemann's original treatment.

Another paper of general interest was by Noether, "Mittheilungen über Riemann's Vorlesungen von 1861-62 über Abel'sche Functionen." This was another step in the undertaking which has been some time on foot to collect and make accessible everything connected with Riemann's scientific activity.

On Tuesday evening there was a grand banquet given in the Odeon. High dignitaries and world renowned savants were present. There were toasts and speeches in profusion. I could not stay to the end, but had to hasten away to take part at a festivity of a more enjoyable kind. This came about so. The members of the Mathematische Vereinigung seem to consider great official banquets rather a tiresome superfluity. At any rate it was well known by past experience that hardly anyone would attend, and so Professor and Mrs. Pringsheim took this opportunity to extend to the members of the Vereinigung and their wives the hospitality of their house, or rather palace, for such it really is in the noble proportions of its rooms and its rare collections of objects of art. Here we were indeed royally entertained. After a rich collation, cigars and the genial flow of mathematical, postprandial speeches were in order.

Wednesday morning was spent in joint session with the naturwissenschaftliche Hauptgruppe of the Gesellschaft. The subject of the papers was the "Decimal division of the circle and unit of time." These gave rise to a lively and prolonged discussion. In the afternoon there were various excursions to points of interest in the surroundings of Munich. The most interesting was to Schleissheim, where a splendid mediæval pageant and an inspection of the treasures of the old castle were the attractions.

Thursday morning the two most interesting papers read were by Brill: "Ueber ein Beispiel des Herrn Boltzmann zur Mechanik von Hertz," followed by an instructive discussion in which Boltzmann took part; and by Study: "Geometrie der Dynamen." The word Dyname, is Plücker's term for a system of forces acting on a rigid body, which, as well known, can be replaced by a couple and a resulting force. Study gave an account of his new geometrical representation of such a system and illustrated its great value; 
one paper by him on this subject has already appeared in the Leipziger Berichte.

In the afternoon a joint session with the Abtheilung für mathematischen und naturwissenschaftlichen Unterricht of the Gesellschaft was held. The papers by H. Weber and Hauck were of great interest. The subject of discussion was the "Ordnung des mathematischen Universitätsunterrichts auf Grund der neuen preussischen Prüfungsordnung." This refers to the new requirements in descriptive geometry, technical mechanics, graphical statics, gendesy, and the adjustment of observations in the state examinations for gymnasial teachers in mathematics. They have been imposed with the purpose of laying more emphasis on applied mathematics and so help fill up to some extent the great gap which is beginning to separate pure mathematics from the practical needs of present sociological conditions. Klein has been identified with this movement from the start and is perhaps. its chief exponent.

From 11 to 1 o'clock the same day the business meeting of the Vereinigung took place. Various reports were made. In the election to replace Hauck and Voss, whose term of office on the council expired, A. Mayer (Leipzig) and Dyck (Munich) were chosen. Later, Mayer has begged to retire in favor of Minkowski, who had received the next highest number of votes. The president for the ensuing year is Hilbert.

I may mention here that a meeting of the academic commission and the editors of the Mathematical Encyclopedia took place some days later and the following arrangement was made for the remaining volumes: Vol. IV, Mechanics, editor, F. Klein ; Vol. V, Physics, editor, A. Sommerfeld; Vol. VI, ( $a$ ) Geophysics, Geodesy, editor, E. Wiechert; (b) Astronomy, editor, H. Burkhardt.

Thursday evening there was a gala presentation at the court theater. The members of the Vereinigung did not care to attend; they had a private entertainment. This was a Kneipe given by the Munich members. It took place in one of the halls of the Neuer Ratskeller, and, as usual, was graced by the presence of the ladies. It was a very pleasant and cordial occasion.

Friday there was again a general session in the royal theater. The address of chief interest to mathematicians was the remarkable paper by Boltzmann, of Vienna: "Ueber die Entwickelung der Methoden der theoretischen Physik in neuerer Zeit.'" The Vereinigung also had a meeting of its own the same day, at which various mathematical papers 
were read, and one by Rudel (Nürnberg) on "Die neue bayrische Prüfungsordnung für das Lehramtsexamen der Lehrer für Mathematik und Physik." This was followed by a long discussion on the questions involved in it and in the previous papers of Weber and Hauck.

Before closing, let me add that the mathematical papers mentioned here, together with many others, will appear ere long in the eighth volume of the Jahresbericht of the Vereinigung. The few remarks I have made will indicate sufficiently their importance and scope. I have, finally, the pleasure of thanking the amiable secretary of the Vereinigung, Prof. Dr. Gutzmer, for notes of the sessions I could not attend.

YALE UNIVERSITY,

James Pierpont. March, 1900.

\section{HILBERT'S FOUNDATIONS OF GEOMETRY.}

Grundlagen der Geometrie. Von Dr. David Hilbert, o. Professor an der Universität Göttingen. (Festschrift zur Feier der Enthüllung des Gauss-Weber-Denkmals in Göttingen. Herausgegeben von dem Fest-Comitee.) Leipzig, Teubner, 1899. 8vo, $92 \mathrm{pp}$.

The committee in charge of the unveiling of the GaussWeber monument at Göttingen has published a memorial volume intended to commemorate the celebration and to serve as a worthy tribute to the genius of the two great men of science. Two professors of the University of Göttingen present in this volume their investigations concerning the foundations of the exact sciences : Professor Hilbert treats of the foundations of geometry ; Professor Wiechert discusses the foundations of electrodynamics. The present notice deals only with the former of these memoirs.

It is the object of geometry to analyze and describe our space intuition. The abstraction from spatial intuition leads to three systems of objects : points, straight lines, and planes, which as elements of such intuition, must lie at the basis of any description of space. By means of definitions these elements are brought into certain correlations for which geometry tends to establish general laws. In order to obtain in this way a logically consistent system of propositions certain requirements, called axioms, must be satisfied by all imaginable mutual relations between the elements. 